\title{
Legal Protection on Intellectual Property Rights in the Development of Creative Economy in Mamuju Regency
}

\author{
Suryansyah
}

STIE Muhammadiyah Mamuju

email: uyasuryansyah@gmail.com

\begin{abstract}
Protection of legal intellectual property rights is the main pillar for businesses, especially those engaged in the creative economy business. The role of law can provide guarantees and legal certainty in creating a good economic climate and increasing people's income derived from the results of the work of creativity, ideas and creativity. The creative economy becomes a strategic issue as a government effort in developing the regional economy, creating a climate of creation and innovation and leading to improving people's welfare. The development of creative economic ventures in Mamuju Regency, West Sulawesi Province must be supported by a set of regional regulations, specifically those that regulate the protection of intellectual property rights of creative economy entrepreneurs. So that business people get protection, justice, benefit and legal certainty related to the work of copyright and innovation products owned. This study aims to examine the regional regulations of Mamuju Regency about the economy, especially the protection of intellectual property rights for creative economic business actors and identify the potential of the creative economy. Data is collected through literature studies to trace data through regional regulation documents. The processed data from descriptive analysis is used as a basis for consideration and review of economic law. The results of this study are in the form of sources of economic law material and manuscripts of academic considerations, where the local government and the public can find out the legal position in the protection of intellectual property rights of creative economy entrepreneurs in Mamuju Regency.
\end{abstract}

Keywords : Legal Protection; Intellectual Property Rights; Creative Economy;

\section{INTRODUCTION}

Intellectual Property is the result of ideas in the form of ideas or ideas that are manifested or expressed in the form of inventions, literary and artistic works, designs, certain symbols/signs, creation of the layout of semiconductor components and breeding varieties. This expression will be a legal product and inherent into an Intellectual Property Rights, Intellectual Property Rights (IPR) if it is processed through applicable procedures and provisions so that IPR can be said to be a legal product in the form of rights arising from intellectual property generated. The intellectual property results are then used in the world of commerce to produce economic value for the inventors/creators of these creations.

In its journey, intellectual property to become a product of IPR requires applicable procedures and procedures, for which regulations are in accordance with the Law and 
government regulations. These procedures and stages are usually considered difficult and complex by intellectual property producers so that there are still many intellectual property results that have not yet been submitted by the IPR. The impact of this condition is that the economic benefits of $\mathrm{KI}$ that have been used by the public have not yet been optimized by intellectual property producers. ${ }^{1}$

A product that can be given IPR protection, then the product must be creative and innovative. A product is said to be creative and innovative in the perspective of IPR that the product can meet the criteria of each IPR regime. For the copyright of a product, it is said to be creative and innovative if it meets the criteria of originality, fixation and creativity. For patents, a product is said to be creative and innovative if the product meets the criteria of novelty, inventive steps and can be applied in industrial activities. must be new and not the same as the previous disclosures, and for trade secrets, the criteria that must be met is an effort to safeguard the information of economic value to the public.

Looking at these criteria, it is clear that the products requested by IPR should be creative and innovative. But unfortunately, currently there are still creative economic actors not paying attention to the existing criteria. As a result, existing products are not new or even counterfeit from pre-existing ones. The reality of IPR protection relating to the IPR registration system is in the form of registration procedures which are considered complicated, costly "expensive" and which tend to be uncertain so that they are not eventually registered. This certainly weakens legal protection and has implications for not protecting the products of the creative economy. Other realities of IPR protection are related to IPR law enforcement.

IPR law enforcement is still considered selective and lacks good and professional treatment. The lack of, law enforcement officers who have a good understanding of IPR also become a real reality in IPR law enforcement. As a result, creative economic products that have been registered with IPR cannot always be protected, even though the legal process should have been carried out.

In general, Intellectual Property Rights can be divided into two categories, namely: Copyright and Industrial Property Rights. Whereas Industrial Property Rights include Patents, Brands, Industrial Designs, Layout Designs of Integrated Circuits, Trade Secrets and Plant Varieties.

Intellectual Property Rights have been regulated by various laws and regulations in accordance with the demands of TRIPs, namely Law Number 29 of 2000 (Plant Variety Protection), Law Number 30 of 2000 (Trade Secret), Law Number 31 of 2000 (Industrial Design) Law Number 32 of 2000 (Layout Design of Integrated Circuits), Law Number 14 of 2001 (Patent), Law Number 15 of 2001 (Trademark), and Law Number 28 of 2014

\footnotetext{
${ }^{1}$ Mujiyono, M., \& Ferianto, F. (2017). Buku Praktis: Memahami dan Cara Memperoleh Hak Kekayaan Intelektual. Yogyakarta: Sentra HKI Universitas Negeri Yogyakarta, p. 1.
} 
(Copyright). The issue of IPR itself is a problem that is quite difficult to overcome, aside from the application of legal regulations regarding copyright, it is still quite difficult, then Copyright violators are increasingly increasing and increasingly difficult to act on, first the issue of improving the performance of legal instruments (law enforcement) which needs to be improved, here are some data regarding prosecution of intellectual property rights violations.

Data from the Directorate of Economic and Special Crimes at Bareksrim Polri said that copyright cases were the most common in the period of $2011-2016$. There were 616 cases, 274 cases, 16 design cases, 7 case patents and 3 case trade secrets. Director General of Intellectual Property Right, Aidir Amin Daud said that his party synergized with law enforcement in dealing with intellectual property piracy. "The problem of pirated products is actually not only centred on the middle class community, but also can reach the government or large corporations. Indeed, all parties need to be educated," he said. Chairperson of the Indonesian Anti-Counterfeiting Society or Masyarakat Indonesia Anti Pemalsuan (MIAP) Justisiari P. Kusumah said the big risk for internet users in Indonesia was an attack on customer data, such as the one currently being handled by the Agency of the Republic of Indonesia Police criminal resort.

In a recent study entitled Cybersecurity Risks from Non-Genuine Software from the Faculty of Engineering, National University of Singapore (NUS), 92\% of computers and laptops using fake software were infected with malware. The study, which was initiated by Microsoft, was completed in June 2017 and covers the Asian region. Pacific. The focus of research is on the risk of malware infections in software from the use of pirated products and active exploitation by cybercriminals from these malicious programs. This study took 458 samples from eight Asia Pacific countries, such as Indonesia, Sri Lanka and Thailand. The samples taken were divided into 203 pirated software download activities, 90 computers and laptops using pirated software, and 165 CDs and DVDs with pirated software. In his presentation, Assistant General Counsel of Microsoft Asia Digital Crime Unit Keshav S. Dhakad explained that the software for productive activities ranked the highest among those infected with malware with a percentage of $42 \%$, followed by the operating system (29\%), games and applications (19\%) and antivirus (17\%). ${ }^{2}$

With the explanation presented by the author above, it can be drawn the legal problem of protecting intellectual property rights in the development of the creative economy in Mamuju Regency, namely, how is the legal position of the protection of intellectual property rights of creative economy entrepreneurs in Mamuju Regency.

\footnotetext{
${ }^{2}$ Issetiabudi, D. E. (2017). Penegakan Hukum: Kasus Hak Cipta Paling Banyak Muncul. Bisnis.com. Retrieved from https://kalimantan.bisnis.com/read/20171011/439/697940/javascript
} 


\section{METHOD}

This study uses descriptive analysis, analysis of data tailored to the purpose of the study which includes the analysis used for fact-finding which is then interpreted according to the research problem. Descriptive analysis is done to find out the existence of independent variables, both on one or more variables without making comparisons and looking for the relationship of the variable with other variables. Descriptive analysis will get a picture related to the legal position in the protection of Intellectual Property Rights of creative economy entrepreneurs in Mamuju Regency, West Sulawesi Province. This research was conducted in January to February 2019 which focused on the area of Mamuju Regency, West Sulawesi. The type of data consists of primary data and secondary data. Primary data was obtained using the interview method with the regional government of Mamuju Regency. While secondary data was obtained from the Legislation Regulations, the Central Bureau of Statistics and the Office of Cooperatives and Micro, Small and Medium Enterprises of the Mamuju District Government, and used interview data collection techniques and library studies.

\section{ANALYSIS AND DISCUSSION}

\section{A. The Concept of Creative Economy}

Creativity is a desire to create something new, unique, and different. The creative industry is an industry that originates from the use of creativity, skills and individual talents to create prosperity and employment through the creation and utilization of the individual's creative and creative power. Meanwhile, the creative economy according to the First Dictum of Indonesian Presidential Instruction Number 6 the year 2009 concerning the Development of the Creative Economy: "Economic activities based on creativity, skills and individual talents to create the creative and creative power of individuals who have economic value and influence the welfare of the Indonesian people."

Urgency of the creative economy includes: Promoting sustainable economic growth because of ideas and creativity are always renewable resources; Lifting the image and identity of the Indonesian nation through works and products, as well as creative people who gain recognition in the international community and also become mediators of cross-national cultural diplomacy; And preserving natural resources and cultural resources of Indonesia, because creative economy is a sector that can create products and works with high added value with limited resources. ${ }^{3}$

\footnotetext{
${ }^{3}$ Nonalisa, S., Isnawati, S., Satika, A., Sukma, W. L., Wirbuana, P. W., Prastyo, J. I., \& Sakinah, P. (2017). Tenaga Kerja Ekonomi Kreatif 2011 - 2016 (R. Agustiyani, E. Sriyanto, \& K. Bachrun Eds.). Jakarta: Badan Pusat Statistik bekerjasama dengan BEKRAF, p. 9.
} 
Types of Creative Economy Sub-sectors: ${ }^{4}$

1. Craft, parts of applied art that are the meeting point between art and design that are sourced from traditional heritage or contemporary ideas whose results can be in the form of works of art, functional products, decorative and decorative objects, and can grouped based on material and exploration of the technical tools used, and also thematic products.

2. Culinary, activities of preparation, processing, presentation of food and beverage products that make elements of creativity, aesthetics, tradition, and/or local wisdom; as the most important element in enhancing the taste and value of the product, to attract purchasing power and provide experience for consumers.

3. Fashion, A lifestyle in appearance that reflects self-identity or group.

4. Architecture, a manifestation of the results of the application of knowledge, science, technology, and the whole in composing the built environment and space, as part of human culture and civilization so that it can unite with the entire space environment.

5. Interior Design, activities that solve the function and quality problems of the interior, provide services related to interior space to improve the quality of life; and fulfil the aspects of health, security, and public comfort.

6. Visual Communication Design, arts of communication by using visual language delivered through the media in the form of a design that aims to inform, influence and change the behavior of the target audience in accordance with the goals to be realized. In this case, the form used is in the form of graphics, signs, symbols, illustrations/photographs, typography/letters and so on.

7. Product Design, a element of advancing the industry so that the industrial products can be accepted by the community because the products they get have good quality, affordable prices, attractive designs, get guarantees and so on. The Industrial Design Society of America (IDSA) defines product design as a professional service that creates and develops concepts and specifications that optimize the function, value and appearance of a product and system for the benefit of both users and manufacturers.

\section{B. Intellectual Property Rights in Creative Economy Development}

IPR abbreviated as Intellectual Property Rights ${ }^{5}$ and Bambang Kesowo defines IPR as a right to wealth that arises or is born due to human intellectual abilities ${ }^{6}$

\footnotetext{
${ }^{4}$ /bid., p. 10.

${ }^{5}$ The opinion of Robert M. Sherwood, Intellectual Property and Economic Development, Sherwood stated that there are two meanings contained in the concept of Intellectual Property Rights. First, private creativity. Second, public protection forthe result of creativity. Vide Kurnia, T. S. (2011). Perlindungan Hukum Merek Terkenal di Indonesia Pasca Perjanjian TRIPs. Bandung: PT. Alumni, p. 105.

${ }^{6}$ Kesowo, B. (1998). GATT, TRIPs dan Hak Atas Kekayaan Intelektual (HAKI). Jakarta: Mahkamah Agung RI, p. 160 .
} 
Jill Mc Keough and Andrew Stewart define IPR as a set of rights granted by law to protect economic investment from creative endeavors. While the Director General of Intellectual Property Rights in collaboration with ECAP defines IPR as the rights arising from the results of brain thinking that produces a product or process that is useful for humans. ${ }^{7}$

The IPR classification after the Uruguay Round is contained in an agreement called the TRIPs Agreement. This is more specifically regulated in Part II about Standards of the Availability Scope and Use of Intellectual Property Rights. More complete classification of IPR based on TRIPs Agreement consists of: 1) copyrights and related rights; 2) trademarks; 3) geographical indications; 4) industrial designs; 5) patent; 6) layout Designs (Topographies) of Integrated Circuits; 7) Protections of Undisclosed Information; 8) Control of Anti-Competitive Practices in Contractual Licenses.

In Indonesia, in classifying IPRs it does not fully adapt to the division as in the TRIPs Agreement, even though in terms of norms it has been adjusted to the standards contained in the TRIPs Agreement. The classification of IPR in Indonesia can be seen as follows: 1) copyright and related rights; 2) patents; 3) brand; 4) industrial design; 5) integrated circuit layout design; 6) trade secrets; 7) protection of plant varieties. Conceptually each part of the IPR above can be described in detail as follows. Copyright is an exclusive right for the creator or recipient of the right to announce or reproduce his work or give permission to do so by not reducing the restrictions according to applicable laws and regulations. The scope of copyright includes the results of intellectual work in the form of works of art, literature and science. Copyright is obtained automatically when the work is manifested. However, it is possible to register copyright requirements with the Directorate General of IPR the Indonesian Ministry of Law and Human Rights.

The period of copyright protection stipulated in the provisions of copyright law in Indonesia is quite varied, namely; The first is valid for the life of the creator and continues until 50 (fifty) years after the creator dies, for the type of work in the form of books, pamphlets, and all other written works, drama or musical drama, dance, choreography, all forms of art, such as painting, sculpture and sculpture, batik art, songs or music with or without text, architecture, lectures, lectures, speeches and other similar creations, props, maps, translations, interpretations, adaptations, and flowers. Second, valid for 50 (fifty) years from the first time the publication is in the form of a computer program, cinematography, photography, database, and the result of the transfer of material and thirdly, the work controlled by the state applies indefinitely. Patents mean exclusive rights granted by the state to inventors or the results of their

7Utomo, T. S. (2010). Hak Kekayaan Intelektual (HKI) di Era Global: Sebuah Kajian Kontemporer. Yogyakarta: Graha IImu, p. 2. 
inventions in the field of technology, which for a certain period of time carry out their own inventions or give their consent to other parties to carry out them.

The scope of patents ${ }^{8},{ }^{9},{ }^{10}$ is in inventions in the field of technology which are problem-solving. This invention has the form of a product or process or it can also be the development/improvement of a product or process. The requirements of an invention can be substantially patented, there are three, namely; novelty requirements, inventive step requirements and can be applied in applicable industries. Patents are obtained by registration (first to file principle). However, in some countries such as the United States patents are obtained based on the first to invent principle. Indonesia itself adheres to the registration system (first to file principle). Registration is done to the Directorate General of the Ministry of Law and Human Rights of the Republic of Indonesia. There are two types of patents, namely patents and simple patents. The period of protection for patents is 20 (twenty) years from the date of receipt and the time period cannot be extended. A simple patent is given for a period of 10 years from the date of receipt and the period cannot be extended.

About brand ${ }^{11}$ is a sign in the form of an image, name, letters, numbers, and arrangement of colours or a combination of all those that have a distinguishing power and are used in the activity of trading goods or services. Rights to the brand can be obtained through the registration system (first to file principle) not based on the first use system (first to use principle). In Indonesia, to obtain brand rights, it must go through a registration system. If the brand has been registered, the rights to the brand arise. The right to the brand is an exclusive right granted by the state to the owner of the brand registered in the General Register of Marks for a certain period of time by using the brand itself or giving permission to other parties to use it.

There are two types of brands, namely trademarks and services. Trademarks are brands that are used on goods traded by a person or several people jointly or a legal entity to distinguish from other types of goods. Service marks are brands that are used on services traded by a person or several people jointly or legal entities to differentiate from other similar services. The period of protection for the brand is 10 years from the date of receipt and the period of protection can be extended.

${ }^{8} 8$ History of patent applications in Indonesia can be seen in Maulana, I. B. (2000). Penerapan Paten Sejak UU Paten No. 6 Tahun 1989 hingga UU Paten No. 13 Tahun 1997. In I. B. Maulana, R. Khairandy, \& Nurjihad (Eds.) Kapita Selekta Hak Kekayaan Intelektual (Vol. 1). Yogyakarta: Pusat Studi Hukum UII Yogyakarta bekerjasama dengan Yayasan Klinik HaKI Jakarta.

${ }^{9}$ Khairandy, R. (2000). Pengalaman Indonesia Selama Ini. In I. B. Maulana, R. Khairandy, \& Nurjihad (Eds.) Kapita Selekta Hak Kekayaan Intelektual (Vol. 1). Yogyakarta: Pusat Studi Hukum UII Yogyakarta bekerjasama dengan Yayasan Klinik HaKI Jakarta.

${ }^{10}$ Purwaningsih, E. (2005). Perkembangan Hukum Intellectual Property Rights: Kajian Hukum terhadap Hak atas Kekayaan Intelektual dan Kajian Komparatif Hukum Paten. Jakarta: Ghalia Indonesia.

${ }^{11}$ Brands have a function to differentiate; guarantee function; promotion function; and investment stimulation and economic growth functions. Vide Purwaningsih, E. (2012). Hak Kekayaan Intelektual (HKI) dan Lisensi. Bandung: CV. Mandar Maju, p. 53. See also Astarini, D. R. S. (2009). Penghapusan Merek Terdaftar. Bandung: PT. Alumni. 
The industrial design scope covers the creative aspects of form, configuration and composition which contain aesthetic elements which are usually used in industrial and craft activities. The right to industrial design itself is obtained by using a registration system. After registration of an industrial design, the right to industrial design arises. The right to industrial design is the exclusive right granted by the Republic of Indonesia to the designer for his creation for a certain period of time carrying out his own approval or consent others to implement this right. The period of protection for industrial design is 10 years from the date of receipt.

The scope of trade secrets includes information that is personal, has economic value and is kept confidential. To obtain the right to trade secrets is based on fulfilling the requirements of the trade secret itself. IPR, when connected with the development of the creative economy, has a very strong relationship. The relation lies in; First, IPR can become an institution in producing creative economic products that are more innovative and contain novelty elements. This understanding is obtained, wherein the IPR is known as the IPR database system that is useful and useful for the development of a product including creative economic products; Secondly, IPR can be used as an instrument for efforts to document a creative and effective economic product. In documenting creative economic products through IPR it is usually documented that it is not only related to the product itself, but also includes product-producing documentation accompanied by shreds of evidence of the law; and Third, IPR can be used as a means in terms of legal protection for a creative economic product. In this IPR system every person who has succeeded in making a product, then by taking certain procedures, he can be considered as the holder of exclusive rights. With the possession of exclusive rights, he can defend from other parties who use it in a legal manner.

\section{Trademark Protection and Legal Problem Issues in the Development of the Creative Economy.}

Creative industries in Indonesia, as written in the 2009 - 2015 National Creative Economy Development Blueprint (2008) are: "Industries originating from the use of creativity, individual skills and talents to create prosperity and employment through the creation and utilization of the individual's creative and creative power." It can be concluded that the Creative Economy in conjunction with the Creative Industry is an economic activity that includes industry with the creativity of human resources as the main asset for creating economic added value. ${ }^{12}$

Linkages to intellectual property rights that usually intersect with the law. Intellectual property consists of:

\footnotetext{
${ }^{12}$ sgrhrbstn. (2013, 2 April). Ekonomi Kreatif by indonesiakreatif.net. sgrhrbstn. Retrieved from https:// sgrhrbstn.wordpress.com/2013/04/02/ekonomi-kreatif-by-indonesiakreatif-net/
} 
- copyright,

- industrial property rights,

- patents,

- industrial design,

- brands,

- integrated circuit layout design,

- trade secrets, and

- plant varieties.

Every creative economy needs a distinguishing element when starting its business. This differentiating element is not only from the form of product or service that is presented but also included in the brand. This is what makes the brand an essential element or important in every creative economy that is run. The origin of the brand actually dates back to medieval times in Europe, namely when trade with the outside world began to develop. The function of the original brand is only to show the origin of the product in question. Only after the introduction of mass production methods and with a wider and more complex distribution and market network, the function of the brand developed into what is known in the present. ${ }^{13}$

According to Amalia Roosseno, actually in Indonesia the brand law has been developed to arrive at the regulation of trade dress, namely in 1930 when the Medan District Court (Landraad) judge examined the COLGATE vs. MAISING case. ${ }^{14}$

Law Number 15 year 2001 concerning Trademark is then changed to Law Number 20 of 2016 concerning Trademarks and Geographical Indications itself giving an understanding of brands and being divided into trademarks and service marks. A brand is a sign in the form of an image, name, word, letters, numbers, arrangement of colours, or a combination of these elements which have distinguishing features and are used in the activity of trading goods or services. Trademarks are Trademarks that are used on goods traded by a person or several people jointly or entities on services traded by a person or several people jointly or a legal entity to differentiate from other similar services.

In Article 3 of Law Number 15 of 2001 concerning Trademark Law Number 20 year 2016 concerning Trademark, it is determined that the Right to Trademark is an exclusive right granted by the State to the Trademark owner registered in the Trademark General Register for a certain period of time using the trademark itself or give permission to other parties to use it. So those who own this brand are the owners

${ }^{13}$ Kesowo, B. (1995). Pengantar Umum Mengenai Hak Atas Kekayaan Intelektual (HAKI) di Indonesia. In Penataran Dosen Hukum Dagang Se-Indonesia. Yogyakarta: Universitas Gadjah Mada, p. 16.

${ }^{14}$ Rooseno, A. (2004). Aspek Hukum Merek. In Lokakarya Terbatas Masalah-Masalah Kepailitan dan Wawasan Hukum Bisnis Lainnya. Jakarta: Mahkamah Agung bekerjasama dengan Pusat Pengkajian Hukum. Vide Hendrawan, D. (2015). Ekonomi Kreatif dan Merek. Zenit, Universitas Kristen Maranatha, 4(1), p. 22. 
of those who register the brand for the first time and who have good intentions. This intention was seen at the time of registration of the mark.

Not all brands can be registered. There are several brands that cannot be registered. Trademarks that cannot be registered are brands that contain elements:

- Contrary to applicable laws and regulations, religious morality, decency, or public order;

- Does not have distinguishing power;

- Has become public property; or

- Is a statement or relating to goods or services that are requested for registration.

In addition to brands that are prohibited from being registered, when they have been requested, the directorate general can also cancel brands that have elements:

- Having equality in principle or in whole with Marks owned by other parties that have been registered in advance for similar goods and/or services;

- Having equality in principle or in whole with a Mark which has been known to belong to another party for similar goods and/or services;

- Similarities in principle or the whole with known -geographic indications;

- Resembles the name of a famous person, photo, or name of a legal entity owned by another person, except with written consent from the rightful person;

- Imitation or resembles a name or abbreviation of a name, flag, symbol or symbol or national or international institution, except with written approval from the competent party;

- Imitation or resembles a sign or stamp or official stamp used by the State or Government institution, except with written approval from the competent authority.

Brand holders are entitled to legal protection as long as the mark is registered. Registered trademarks receive legal protection for a period of 10 years from the Acceptance Date and the period of protection can be extended. The registered Brand Owner can apply for an extension for the same period of time each time. Application for the extension as referred to in paragraph (1) shall be submitted in writing by the owner of the Mark or his Authority within 12 months prior to the expiration of the registered Mark's protection period. The application for the extension is submitted to the Directorate General of Intellectual Property Rights. The application for the extension of the brand will be approved if the:

- mark concerned is still used in the goods or services as mentioned in the Brand Certificate; and

- goods or services that are extended by their brands are still produced and traded.

In terms of supporting users of well-known brands and also increasing the popularity of a brand or product, this brand can be transferred to other parties. Rights to registered Marks can be transferred or transferred because: 
- Inheritance;

- Will;

- Grant;

- Agreement; or

- $\quad$ other causes justified by the laws and regulations.

The transfer of rights to the Mark shall be requested for registration to the Directorate General of Intellectual Property Rights to be recorded in the General Register of Brands accompanied by supporting documents and announced in the official news of the brand. If the transfer of rights to the registered trademark is not recorded, it may not be detrimental to the other party. The transfer of rights to a registered Mark can be accompanied by the transfer of good name, reputation, or others related to the Mark, but the right to a registered Service Mark that cannot be separated from the ability, quality, or personal skills of the service provider can be transferred with the provision must be guaranteed. the quality of service delivery.

According to Law Number 15 of 2001 concerning Trademarks, Law Number 20 year 2016 concerning Trademarks Owners of registered Brands have the right to give licenses to other parties under an agreement that the licensee will use the Mark for part or all types of goods or services. The License Agreement is valid throughout the territory of the Republic of Indonesia unless otherwise agreed, for a period not longer than the protection period of the registered Mark concerned. Registration of licenses must be filed with the Directorate General with fees and legal provisions from the recording of the licensing agreement in force to the parties concerned and to third parties.

According to Law Number 15 year 2001 concerning Trademarks. Law Number 20 year 2016 concerning Trademarks, License Agreements are prohibited from making provisions that directly or indirectly can cause adverse effects on the Indonesian economy or contain restrictions that impede the ability of the Indonesian nation to master and develop technology in general. it is cancelled on the basis of equality in principle or the whole with other registered Marks, still entitled to carry out the License agreement until the end of the License agreement period and is no longer obliged to continue the royalty payment to the canceled Licensor, but must pay royalties to the owner of the brand that is not canceled.

\section{Legal Standing for the Protection of Intellectual Property Rights Against the} Development of Creative Economy in Mamuju Regency

Regency is one of the districts formed based on Law Number 29 the year 1959 concerning the Formation of Level II Regions in Sulawesi within the territory of the South Sulawesi Province. Mamuju is the capital of West Sulawesi Province, 
which holds a million treasures. Starting from a very strategic location, a large area to abundant natural wealth. This area has an area stretching from the border of Tapalang District to Sampaga District. Mamuju is directly opposite the Makassar Strait and Kalimantan Island in the west which is a bustling national trade route and the Trans Sulawesi West Coast land route which is the main trade route that connects cities on the island of Sulawesi. Besides having a very strategic location, Mamuju Regency also has abundant natural wealth even though until now most of its potential has not been well managed.

The potential of natural resources owned by this region comes from several sectors, namely: Agriculture and Animal Husbandry Sector, Plantation and Forestry, fisheries and marine affairs, and the Mining and Energy Sector. In addition, to reach Mamuju Regency which is also the capital of West Sulawesi Province which is the $33^{\text {rd }}$ Province in Indonesia can be reached by aeroplane based at Tampapadang Airport, Kalukku District, about 35 kilometres from Mamuju City.

Other supporting factors include accommodation facilities such as adequate hotels and inns, restaurants and restaurants and telephone facilities in the form of Telkom and cellular telephones as well as banks that are ready to serve the needs of prospective investors visiting the area. Especially for tourism, this area also has potential that is not inferior to other regions. The tourism potential is in the form of marine tourism, nature tourism and cultural tourism. In the city of Mamuju itself, the Mamuju Regional Government has been trying to build a creative economy through government programs, one of which is the development of a creative economy through the use of local food processing to support the increase in income per capita of the community. ${ }^{15}$

Creative economic development is in line with the mission of the Mamuju District Government, namely to increase the ability and economic independence of the community, through business development and home industry and support for improving public transportation, said Mamuju Regent Habsi Wahid. He conveyed this at the Institute for the Development of Appropriate Local Communities of Indonesian Technology (Lembaga Pengembangan Teknologi Tepat Guna-Masyarakat Lokal Indonesia - LPTTG - Malindo) Director's Expose and the inauguration of the Mamuju Community Economic Business Development Forum (Forum Pengembangan Usaha Ekonomi Masyarakat - FPUEM) which took place in the local Regent's Office Pattern Room on Sunday. Therefore, he said, the Mamuju District Government invited every village in Mamuju Regency to utilize the food in their respective regions. No doubt, Mamuju is rich in local food such as corn, cassava, pumpkin and several other local

${ }^{15}$ Putra, A. H. P. K., Nasir, M., \& Buana, A. P. (2018). Mengungkap Keberhasilan Tax Amnesty: Studi Kasus pada KPP Pajak Pratama Makassar Utara. Jurnal Akuntansi dan Pajak, Sekolah Tinggi IImu Ekonomi AAS Surakarta, 19(1), p. 66. 
foods. "The economic opportunity in Mamuju is very large. So we try to generate creative economic activities in Mamuju, one of which is by processing the food around us. I hope that every village has a superior product of the creative economy," Habsi said.

So, he said, the active role of economic actors in each village is highly expected, especially the role of the Pemberdayaan Kesejahteraan Keluarga (PKK) driving team in each village to be able to spearhead the creative economic activities. "The PKK driving team can provide guidance to every creative economic actor in his area. This is what should be used as well as possible," he said. On the same occasion, Director of LPTTG - Malindo Sakaruddin also exposes the business he initiated in Masamba district, South Sulawesi, which has succeeded in processing approximately 260 types of marine, agricultural and plantation fisheries products. being dried food (snacktortilla) worthy of local/export market products. In the brief meeting, Sakaruddin had time to share tips on success in carrying out creative economic activities. According to him, economic actors must work by combining the brain, muscle and heart to achieve maximum results. "Capital is not the main thing but skill and mindsets, both tools and the third is capital," said Sakaruddin. Demonstrating its seriousness in processing food into a product of the creative economy of the community, the Mamuju District Government gave every village the opportunity to send four representatives of creative economic actors to study directly at LPTTG-Malindo, for 10 days. With hope, the Mamuju district government mission can truly be realized. ${ }^{16}$

Then another effort carried out by the Mamuju Government was the implementation of a Dedicated Day Safari for the People (Sahabat Rakyat) which is a regional government program of Mamuju Regency in bringing services to the community, now looking increasingly creative, with these activities can increase innovation from each sub-district due to activities. This activity, one of which is a creative economic exhibition, produces local products from the Mamuju region and even the regional government hopes that this program can survive and be carried out in other areas in Mamuju Regency. ${ }^{17}$

From the creative ideas that emerged in Mamuju Regency is a positive trend that is present in the Mamuju area which is the capital city of West Sulawesi Province which is starting to develop, this is a normal trait for developing regions, because the regions that develop automatically lead to conditions the community is also developing, one of the things we mentioned above is creative ideas that can be used as a source of income and an increase in the regional economy, as we know the Mamuju region

${ }^{16}$ Ahmad, A. (2016). Mamuju Kembangkan Ekonomi Kreatif. AntaraNews.com. Retrieved from https:// makassar.antaranews.com/berita/74512/mamuju-kembangkan-ekonomi-kreatif

${ }^{17}$ Bukhori, S. A. (2018). Bupati Mamuju Kunjungi Pameran Ekonomi Kreatif di Sampaga. MamujuPos.com. Retrieved from https://mamujupos.com/bupati-mamuju-kunjungi-pameran-ekonomi-kreatif-di-sampaga 
which has the potential for agriculture quite rapidly, and is one of the biggest sources of income from the community. however, with the emergence of creative ideas, collaboration between natural resources in Mamuju Regency and creative ideas of the community will produce creative economies which are now fully supported by the Central Government through the establishment of an institution called the Creative Economy Agency (Badan Ekonomi Kreatif - BEKRAF) Then there is no reason for the regional government to refuse or not support the development of the creative economy in the region, because the central government has fully supported its aim to empower the people in each region, through the development of a creative economy.

In addition, the process of development of the creative economy must be supported by digitalization systems or what we are more familiar with information digitalization, namely the process of transforming various information, news from analogue format into format digital so that it is easier to produce, store, manage, and distribute. Information that is digitalized can be presented in the form of text, numbers, audio, visual, which contains ideology, social, health and business. So many products from creative economic actors are not in line with expectations or behavior, one of the reasons is problematic marketing process, then constrained on the issue of promotion, especially when the promotion and advertising are no longer carried out as before through brochures or print media, almost all promotions are carried out through internet media, both websites, blogs and social media, because in the digitalization era as now information is more and faster obtained through the internet than through print media.

So the discussion above we can see that the issue of intellectual property rights will have an impact on the problem of increasing the creative economy, one of which is the issue of the use of trademarks, for example in Mamuju Regency, which will develop creative economies. especially from the Regional Government so that the products sold have legal certainty and are not problematic in the future.

The government's efforts in overcoming the problem first are direct assistance in improving the creative economy, especially in the area of public understanding of the importance of trademark registration so that trademarks used by creative economic actors in Mamuju Regency have legal certainty about the products produced in accordance with potential resources nature owned by Mamuju Regency, Second is the making of regulations in the form of Regional Regulations that specifically provide legal certainty for creative economic business actors even though it has been regulated in the brand law, there is no harm in Regional Government also supporting through the creation of Regional Regulations that protect economic actors creative and creative economy improvement in Mamuju district, because the potential in a region that knows better is the local government itself, so the Regional Government 
should make regulations regarding issues of intellectual property rights intestine to improve the Creative Economy in Mamuju district.

\section{CONCLUSION}

Creative industries cannot develop independently and separate from other sectors. Creative industries support each other and collaborate with other sectors, starting from the education, technology, trade, tourism, defence, politics, social and cultural sectors. Creative products are created and distributed on various platforms. In the current Mamuju Regency, a trend that has begun to grow among young people, the strengthening of creative economic activities. We can observe this in business growth, especially in the Manakarra Coast region. It's just not yet become a large and significant industry and the availability of facilities in its development. The products produced are also tailored to the minimal market demand, and most marketing methods are marketed in a simple way, for example through the internet, social media, and from door to door. Indonesia has a regulation that is assessed in accordance with the rules in the Creative Economy, namely Law Number 20 the year 2008 concerning MSMEs, Law Number 33 the year 2009 concerning Film - encouraging the development of the film industry, Law Number 3 the year 2014 concerning Industry - encourages the development of the National creative industry, Law Number 28 the year 2014 concerning Copyright - provides intellectual property protection for creative works, and Law Number 7 the year 2014 concerning Trade - Encourages product trade based on the creative economy. The Regional Government of Mamuju Regency needs to formulate a regional regulation that can provide legal guarantees and certainty to the intellectual property of creative entrepreneurs in Mamuju Regency.

Currently in Mamuju Regency West Sulawesi Province does not yet have a creative industry centre, both from production and marketing activities. It is important, the local government to build complex and creative industrial facilities, where each actor and creative industry elements collaborate with each other and are easy to bring together creative industry producers and consumers. Everything will not be achieved properly, if it is not supported politically by the ruling party or in other words if there is no political-will from each stakeholder, especially for the Mamuju Regional Government.

\section{REFERENCE}

Ahmad, A. (2016). Mamuju Kembangkan Ekonomi Kreatif. AntaraNews.com. Retrieved from https://makassar.antaranews.com/berita/74512/mamuju-kembangkanekonomi-kreatif

Astarini, D. R. S. (2009). Penghapusan Merek Terdaftar. Bandung: PT. Alumni. 
Bekraf. (2017). Rencana Pengembangan Ekonomi Kreatif Indonesia (Vol. 1). Jakarta: Badan Ekonomi Kreatif.

Bukhori, S. A. (2018). Bupati Mamuju Kunjungi Pameran Ekonomi Kreatif di Sampaga. MamujuPos.com. Retrieved from https://mamujupos.com/bupati-mamujukunjungi-pameran-ekonomi-kreatif-di-sampaga

Djumhana, M., \& Djubaedillah, R. (1997). Hak Milik Intelektual: Sejarah, Teori dan Prakteknya. Bandung: PT. Citra Aditya Bakti.

Hendrawan, D. (2015). Ekonomi Kreatif dan Merek. Zenit, Universitas Kristen Maranatha, $4(1), 17-24$.

Hill, N. (2007). Berpikir dan Menjadi Kaya (A. Subiyanto, Trans.). Jakarta: Ramala Books. Issetiabudi, D. E. (2017). Penegakan Hukum: Kasus Hak Cipta Paling Banyak Muncul. Bisnis. com. Retrieved from https://kalimantan.bisnis.com/read/20171011/439/697940/ javascript

Kesowo, B. (1995). Pengantar Umum Mengenai Hak Atas Kekayaan Intelektual (HAKI) di Indonesia. In Penataran Dosen Hukum Dagang Se-Indonesia. Yogyakarta: Universitas Gadjah Mada.

Kesowo, B. (1998). GATT, TRIPs dan Hak Atas Kekayaan Intelektual (HAKI). Jakarta: Mahkamah Agung RI.

Khairandy, R. (2000). Pengalaman Indonesia Selama Ini. In I. B. Maulana, R. Khairandy, \& Nurjihad (Eds.), Kapita Selekta Hak Kekayaan Intelektual (Vol. 1). Yogyakarta: Pusat Studi Hukum UII Yogyakarta bekerjasama dengan Yayasan Klinik HaKI Jakarta.

Kurnia, T. S. (2011). Perlindungan Hukum Merek Terkenal di Indonesia Pasca Perjanjian TRIPs. Bandung: PT. Alumni.

Maulana, I. B. (2000). Penerapan Paten Sejak UU Paten No. 6 Tahun 1989 hingga UU Paten No. 13 Tahun 1997. In I. B. Maulana, R. Khairandy, \& Nurjihad (Eds.), Kapita Selekta Hak Kekayaan Intelektual (Vol. 1). Yogyakarta: Pusat Studi Hukum UII Yogyakarta bekerjasama dengan Yayasan Klinik HaKI Jakarta.

Mujiyono, M., \& Ferianto, F. (2017). Buku Praktis: Memahami dan Cara Memperoleh Hak Kekayaan Intelektual. Yogyakarta: Sentra HKI Universitas Negeri Yogyakarta.

Nonalisa, S., Isnawati, S., Satika, A., Sukma, W. L., Wirbuana, P. W., Prastyo, J. I., \& Sakinah, P. (2017). Tenaga Kerja Ekonomi Kreatif 2011 - 2016 (R. Agustiyani, E. Sriyanto, \& K. Bachrun Eds.). Jakarta: Badan Pusat Statistik bekerjasama dengan BEKRAF. 
Purwaningsih, E. (2005). Perkembangan Hukum Intellectual Property Rights: Kajian Hukum terhadap Hak atas Kekayaan Intelektual dan Kajian Komparatif Hukum Paten. Jakarta: Ghalia Indonesia.

Purwaningsih, E. (2012). Hak Kekayaan Intelektual (HKI) dan Lisensi. Bandung: CV. Mandar Maju.

Putra, A. H. P. K., Nasir, M., \& Buana, A. P. (2018). Mengungkap Keberhasilan Tax Amnesty: Studi Kasus pada KPP Pajak Pratama Makassar Utara. Jurnal Akuntansi dan Pajak, Sekolah Tinggi Ilmu Ekonomi AAS Surakarta, 19(1), 60 - 68.

Rooseno, A. (2004). Aspek Hukum Merek. In Lokakarya Terbatas Masalah-Masalah Kepailitan dan Wawasan Hukum Bisnis Lainnya. Jakarta: Mahkamah Agung bekerjasama dengan Pusat Pengkajian Hukum.

sgrhrbstn. (2013, 2 April). Ekonomi Kreatif by indonesiakreatif.net. sgrhrbstn. Retrieved from https://sgrhrbstn.wordpress.com/2013/04/02/ekonomi-kreatif-by-indonesiakreatifnet/

Usman, R. (2003). Hukum Hak Atas Kekayaan Intelektual: Perlindungan dan Dimensi Hukumnya di Indonesia. Bandung: PT. Alumni.

Utomo, T. S. (2010). Hak Kekayaan Intelektual (HKI) di Era Global: Sebuah Kajian Kontemporer. Yogyakarta: Graha IImu.

Yudistira, A. B. (2016). Regulasi untuk Mendukung Pengembangan Ekonomi Kreatif. Badan Ekonomi Kreatif. Retrieved from https://www.bekraf.go.id/berita/page/8/ regulasi-untuk-mendukung-pengembangan-ekonomi-kreatif 